\title{
ОСОБЕННОСТИ ФОРМИРОВАНИЯ ОЗЕРНЫХ ОТЛОЖЕНИИ В ПОЗДНЕ- И ПОСЛЕЛЕДНИКОВЬЕ
}

Формирование многих озер Северо-Запада СССР связано с таянием ледников последнего оледенения. Донные отложения этих озер отражают особенности природной обстановки периода дегляциации и последующие изменения климата голоцена. Нами изучены колонки донных отложений нескольких крупнейших озер этого региона - Онежского, Лача, Воже и Кубенского, время образования и основные этапы истории которых различны.

Самое южное из исследованных озер, Кубенское, приурочено к древней тектонической впадине, заложение которой относится к доледниковому времени (Ауслендер, Гей, 1967). В начале плейстоцена дочетвертичная поверхность впадины была в значительной мере переуглублена экзарацией ледников (рис. 1). В течение бологовско-едровской стадии валдайского оледенения ледниковый язык занимал всю котловину озера. Радиоуглеродные датировки межморенной толщи на р. Пучке дают возраст покрывающей ее морены порядка 20 тыс. лет (Арсланов и др., 1970). Краевые образования, обрамляющие ледниковый язык, обнаружены по периферии озера.

В Присухонской низине к фронту ледника примыкал крупный приледниковый водоем, который по мере деградации ледника (16-17 тыс. лет назад) заполнил Кубенскую котловину, что привело к образованию Кубено-Сухонского озерно-ледникового бассейна, соединившегося с бассейнами в Молого-Шекснинской и Средне-Шекснинской низинах. Распад

103

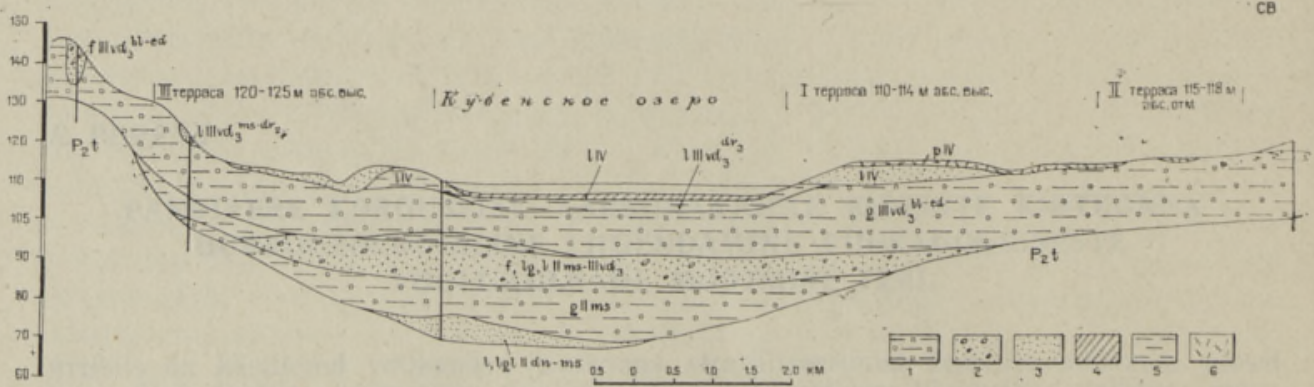

Рис. 1. Геологический разрез через Кубенское озеро по линии д. Мишаково - д. Дор: 1 - суглинки и супеси валунные, 2 - пески с гравием и галькой, 3 - пески, $4-$ илы, 5 - суглинки и глины, 6 - торф. 
Кубено-Сухонского водоема на два самостоятельных озера, по-видимому, произошел в конце плюсского межстадиала, к которому относится начало формирования сквозной III озерной террасы с уровнем $120-125 \mathrm{M}$. Оно завершилось в среднем дриасе, о чем свидетельствуют радиоуглеродные датировқи отложений на р. Пучке от $14300 \pm 310$ до $12210 \pm 210$ лет назад (Ауслендер и др., 1970).

В Сухонском озере к концу позднего дриаса уровень воды упал до 100-105 $м$ абс. высоты. В атлантическое время Сухонское озеро повысило свой уровень до $115 \mu$, и с этого момента начался спуск озера в восточном направлении по долине р. Сухоны. Акватория Кубенского озера в течение голоцена постепенно сокращалась до современного уровня (абс. выс. 110 м). Падение уровня прерывалось рядом более или менее длительных остановок и временных повышений.

Дегляциация и освобождение более низких порогов стока привели к сокращению площади приледниковых озер (Квасов, 1975). Уже во время лужской стадии от Кубено-Сухонского обособнлось Воже-Лачское озеро. Последнее получило сток на север, и гидрологическая сеть этого района приняла в северной части бассейна современный вид: на месте единого Воже-Лачского озера образовались в близких к современным очертаниях озера Лача и Воже.

Нами изучены колонки донных отложений озер в зонах современного илонакопления и характеризующие условия седиментации в глубоких и удаленных от берегов районах озерных котловин.

Морфометрические характеристики озер следующие:

Абсолютная высота, $M$

Площадь, $\kappa м^{2}$

Средняя глубина, $\mu$

Максимальная глубина, $\mu$

Площадь зоны илонакопления, в \% от общей площади озера

$\begin{array}{cccc}\text { Кубенское } & \text { Лача } & \text { Воже } & \text { Онежское } \\ 110 & 118 & 122 & 33 \\ 417 & 345 & 418 & 9930,2 \\ 2,9 & 1,6 & 1,4 & 30 \\ 4,5 & 4 & 4 & 120\end{array}$

57
52
60

В основании разрезов лежат слоистые позднеледниковые глины, перекрытые гомогенными послеледниковыми глинами, на которых залегают илы. В озерах Кубенское, Воже и Лача повсеместно вскрыта бежевая слоистая глина с хорошо выраженными прослойками алеврита и песка. Толщина глинистых слойков не превышает $0,5-0,7 \mathrm{~cm}$, песчано-алевритовых - 0,1-0,3 cм. Исследованная мощность слоистых глин составляет не более 2,5 м; их образование закончилось в позднем дриасе (Хомутова, $1974,1975)$. Слоистые глины в озерах Лача, Воже и Кубенское существенно отличаются от одновозрастных глин в больших водоемах, таких как Ладожское и Онежское озера, для которых характерна ленточная текстура. В верхнем 1,5-метровом слое ленточная текстура микрослоистая (Семенович, 1973; Курочкина, 1976), что свидетельствует о значительном удалении края ледника от акватории озера. Значительная мощность глин говорит о длительном осадконакоплении. Текстуры глин в мелководных озерах слоистые, но микрослоистость в них отмечена лишь на контакте с гомогенными глинами. Видимо, ледник, питавший эти водоемы, отступал здесь значительно быстрее, чем в районе Ладожского и Онежского озер.

Содержание пелитовых фракший в слоистых глинах Кубенского и Вожского өзер достигает $60-70 \%$, на долю коллондной фракции при этом приходится не более $14 \%$, а алевритовые составляют $30 \%$. В лен- 

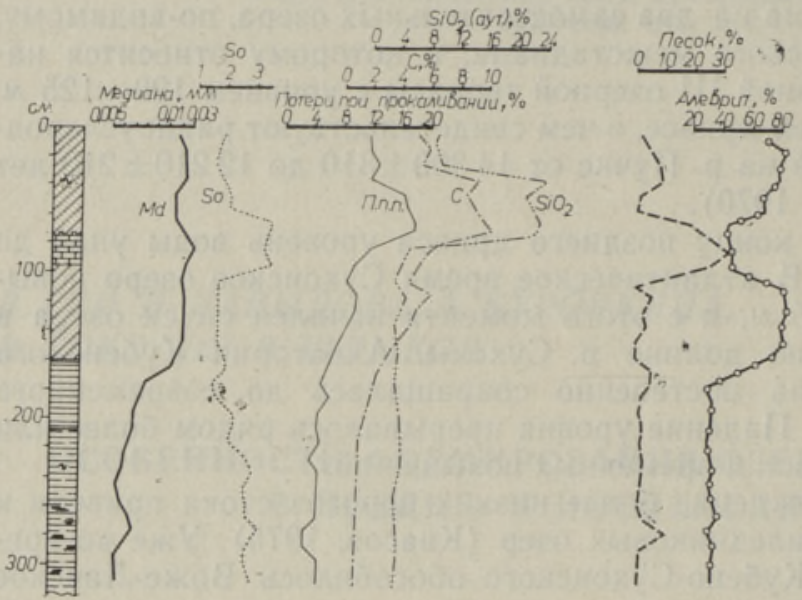

Рис. 2. Гранулометрический состав, органическое вещество и аутигенный кремнезем в донных отложениях Кубенского озера.

точных глинах Онежского озера гранулометрический состав более тонкий: на долю пелитовых фракций в них приходится более $90 \%$, в том числе на коллондную - более $50 \%$.

Содержание органического вещества в

слоистых глинах оз. Кубенское несколько выше $(2,5-4,5 \%)$, чем в осадках оз. Воже $(1,9-3,3 \%)$, углерода в Кубенском до $1,0 \%$ и в Воже $0,5 \%$; аутигенного кремнезема в Кубенском 3-4\% (рис. 2), а в Воже не более $3 \%$.

Мощность послеледниковых гомогенных глин колеблется от нескольких сантиметров до $0,7 м$. Как и в подстилающем горизонте, в них преобладают пелиты (более $60 \%$ ). Особенно тонкие глины характерны для оз. Лача, где содержание коллоидной фракции доходит до $12-18 \%$. Содержание алевритов в них не превышает $30 \%$, песков - до $5 \%$. Резкое погрубение осадков отмечено на контакте глин с илами: количество пелитов снижается здесь до $40 \%$, а алевритов соответственно возрастает до $50 \%$. Средний диаметр частиц $(\mathrm{Md})$ в глинах озер Кубенское и Воже примерно одинаков $(0,007-0,018$ мм), они имеют хорошую сортировку, тогда как в озере Лача она несколько хуже $-\mathrm{S}_{0}=3,3$.

Содержание органического вещества (потери при прокаливании) в Кубенском озере выше (до $5,6 \%$ ), чем в других (до 3,6 в Воже и до $4,2 \%^{\circ}$ в Лача). Количество аутигенного кремнезема также несколько выше (см. рис. 2). В гомогенных глинах Онежского озера на периферических участках содержание органического вещества не превышает $3 \%$, а в центральных частях возрастает до $4,5 \%$.

Гомогенные глины перекрыты илами. В глубоком олиготрофном Онежском озере наблюдается постепенный переход от глин к илам. В мелководных озерах послеледниковое потепление вызвало бурное развитие органической жизни, что привело к образованию илов со значительным содержанием органического вещества. Переход от глин к илам в них резкий. На контакте нередко отмечаются включения песка и алеврита, что свидетельствует о возможном падении уровня озер. Местами на глинах или в илах встречается горизонт белесоватого карбонатного ила, мощность которого в озерах Воже и Кубенское не превышает 0,5 $м$, а в южной части оз. Лача достигает 1,2 м. Верхи гомогенных глин и иловая толща под карбонатным горизонтом в Кубенском озере сформировались в пребореальное время, когда вода достаточно хорошо прогревалась и в озере началось образование илов со значительным содержанием органического вещества и аутигенного кремнезема. Начало илонакопления в озерах Воже и Лача относится к бореальному времени. В Онежском озере илы начали отлагаться лишь с конца атлантики.

Скорости илонакопления в озерах Лача, Воже и Кубенское, несмотря на примерно одинаковые морфометрические показатели их котловин, 
были различными. Так, в оз. Кубенское мощность илов не превышает 1 м, при этом на большей части озера она значительно меньше. В оз. Воже илонакопление приурочено к южной углубленной части, а мощность илов не превышает 2 м. В оз. Лача почти на всей площади его дна илы имеют мощность $2-4 \mathrm{M}$.

Во всех озерах начало илонакопления характеризуется резким погрубением гранулометрического состава осадков. Для карбонатных илов характерно резкое увеличение содержания песчаных фракций, особенно отчетливо проявляющееся в озерах Кубенское и Воже - до 33 и $47 \%$ соответственно. Одновременно отмечается ухудшение сортировки до 3,7 , что говорит о резком снижении уровня озер. Содержание органического вещества возрастает в илах вверх по разрезу: в оз. Кубенское оно достигает 9-18, в Воже - около 9, в Лача от 6 до $15 \%$; содержание аутигенного кремнезема в карбонатных илах оз. Кубенское значительно выше (от 4 до $22 \%$ ), чем в других озерах (до $4 \%$ ).

Над карбонатными илами залегает толща буроватых мелкоалевритовых илов (алевритов до $80 \%$ ). В оз. Лача илы более тонкие: в них содержится $47-68 \%$ алевритов и $25-41 \%$ пелитов. В содержании органического вещества и активного кремнезема также происходят заметные изменения: в оз. Кубенское резко снижается содержание как органического вещества, так и активного кремнезема (соответственно с 18 до 11 и с 23 до 8\%). Максимальное содержание органического вещества наблюдается теперь в илах оз. Лача (потери при прокаливании $18-25$, углерод $10-12$, активный кремний $8-13 \%)$.

В мощной иловой толще оз. Лача в атлантическое время наблюдается заметное погрубение осадков, сопровождающееся увеличением содержания органического вещества. Дальнейшее увеличение содержания последнего приходится на вторую половину суббореала и достигает $25 \%$, что является максимальным для всего разреза. Увеличение содержания органического вещества в это время характерно также для иловых отложений Онежского озера.

Для характеристики минерального состава глинистой фракции $(<0,001$ мм) в различных стратиграфических горизонтах отложений оз. Воже были выполнены рентген-дифрактометрические и электронномикроскопические анализы. Были установлены следующие глинистые минералы: гидрослюды, хлорит, в меньших количествах монтмориллонит и смешанослойные образования, в виде незначительной примеси - каолинит. Из неглинистых минералов обычны кварц, полевые шпаты и амфиболы.

Диоктаэдрическая однослойная гидрослюда является основным глинистым минералом во всех исследованных пробах. Она представлена различными по размеру частицами, чаще всего неправильно-изометрической формы; преобладают частицы размером $0,2-0,4$ мкм. Несмотря на высокую дисперсность, окристаллизованность гидрослюд хорошая.

Триоктаэдрический магнезиально-железистый хлорит, предположительно относящийся к клинохлору, составляет около $15-20 \%$.

Монтмориллонит является, по всей вероятности, продуктом изменения гидрослюд. Смешанослойны е образования в основном типа гидрослюда-монтмориллонит. Помимо них, в незначительных количествах определен хлорит - (вермикулит) монтмориллонитового состава. 'Суммарное содержание монтмориллонита и смешанослойных образований не превышает $20 \%$.

Ка олинит присутствует в небольших количествах и представлен псевдогексагональными частицами или их обломками размером 1 - 
1,5 мкм хорошей окристаллизованности. Встречены также единичные кристаллы галлуазита. Содержание каолинита и галлуазита не превышает $5-8 \%$.

В составе глинистых минералов одновозрастных отложений не наблюдается качественных различий на разных участках дна озера.

Минеральный состав слоистых бежевых глин верхнего дриаса и вышележащих гомогенных серых глин пребореального времени практически идентичен. Отличительной чертой бежевых глин является наличие в заметном количестве щепковидной и удлиненнопластинчатой гидрослюды: в них лучше выражены образования хлорит - (вермикулит) - монтмориллонит. Голубовато-серые гомогенные глины отличаются от бежевых несколько повышенным содержанием в них гидрослюды $(65-70 \%$ микронной фракции) и каолинита (до $8 \%$ ).

Сравнение дифрактограмм глин и залегающих выше по разрезу буровато-серых илов свидетельствует о худшей окристаллизованности глинистых минералов в илах и наличии в их микронной фракции рентгеноаморфного вещества. Различие в минеральном составе выражается в отсутствии в илах монтмориллонита. Несколько больше по сравнению с глинами хлорита (до 20\%) и смешанослойных образований. Отсутствие в илах монтмориллонита говорит о том, что выветривание и эрозия на водосборе в период илонакопления протекали очень слабо.

Донные отложения оз. Воже характеризуются однородностью состава глинистых минералов в различных стратиграфических горизонтах. Тот же комплекс глинистых минералов присущ и пермским отложениям, с выветриванием которых связано присутствие каолинита в осадках озера. Это подтверждает генетическую связь донных отложений с водосбором.

Состав глинистых минералов осадков оз. Воже сходен с одновозрастными отложениями Онежского озера (Семенович и др., 1972), но отличается по структурным особенностям гидрослюд. Для осадков Онежского озера характерны триоктаэдрические гидрослюды, связанные с поступлением в озеро глинистого материала, образующегося при выветривании пород Балтийского кристаллического щита, а диоктаэдрические гидрослюды в отложениях оз. Воже генетически связаны с древними осадочными породами пермского возраста.

Панцири диатомовых водорослей являются главным источником накопления аутигенного кремнезема в донных отложениях озер. Количество диатомей в осадках зависит от интенсивности их развития в планктоне и бентосе озера, а также от степени терригенного разбавления в процессе седиментации и последующих диагенетических явлений. Современные методы позволяют определить количество створок диатомей, содержащееся в грамме осадка, но не дают количественной оценки их роли в осадконакоплении, поэтому в наших исследованиях диатомовый анализ сопровождался послойным определением аутигенного кремнезема. Получена хорошая связь между содержанием аутигенного кремнезема и количеством створок диатомей (рис. 3 ).

Верхнедриасовые слоистые глины в оз. Воже чрезвычайно бедны диатомеями (до 2,3 тыс. створок), тогда как в оз. Кубенское в отдельных горизонтах их содержание достигает 0,5 млн. Диатомовые комплексы в них сходны и представлены литоральными бентосными видами, обитателями дна и обрастаний озерных мелководий. Среди диатомей отмечены холодолюбивые виды, не встречающиеся ныне в этих озерах: Melosira arenaria Moore, Navicula oblonga Kütz. Состав и характер диатомовых комплексов свидетельствует об отложении их на мелководьях.

Содержание диатомей в пребореальных гомогенных глинах озер Воже (до 4 тыс.) и Кубенское (до 1,5 тыс.) низкое, а в относимых к пре- 
Рис. 3. Количество створок диатомовых водорослей и содержание аутигенного кремнезема в отложениях озер Лача, Воже и Кубенское: 1 - ил, 2 - карбонатный ил, 3 - гомогенная глина, 4 - слонстая глина.

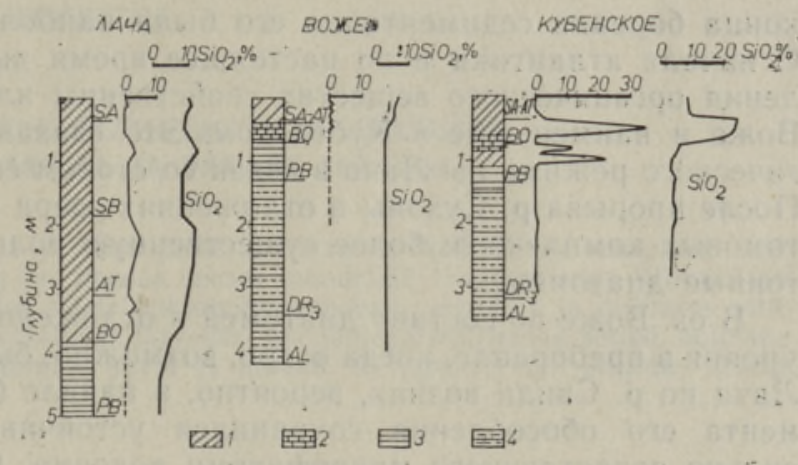

бореалу илах наивысшее (до 22,5 млн.). В пребореальных глинах оз. Лача оно возрастает вверх по разрезу и достигает 12,5 тыс. створок.

Состав диатомовых комплексов пребореала различен. В оз. Воже преобладают планктонные диатомеи рода Cyclotella: C. comta (Ehr.) Kütz., C. operculata (Ag.) Kütz. et var unipunctata Hust. Последняя в более молодых отложениях озера не встречается. В значительных количествах встречены также виды обрастаний и донные.

В двух других озерах в диатомовых комплексах господствуют виды обрастаний, преимущественно рода Fragilaria: F. brevistriata Grun., $F$. construens (Ehr.) Grun. с варьететами, F. inflata (Heid.) Hust. и др., a также Opephora martyi Herib. В оз. Лача найдены Melosira arenaria, M. islandica subsp. helvetica O. Müll., а также Cocconeis disculus (Schum) Cl., показывающие, что водоем имел черты олиготрофии.

В бореальное время в условиях общего потепления климата, в озерах начинается процесс илообразования, численнос́ть диатомей в осадках резко возрастает (до 2 млн. в оз. Лача и 1,5 млн. в оз. Воже), оставаясь наивысшей в оз. Кубенское (до 33,75 млн.), где по-прежнему, как и в Лача, господствуют диатомеи обрастаний. В оз. Воже в бореальное время происходит перестройка диатомового комплекса: планктонные виды утрачивают свою роль, возрастает значение диатомей обрастаний: Fragilaria construens, $F$. lapponica Grun., $F$. virescens Ralfs.

B атлантическое время в озерах устойчиво доминируют диатомеи обрастаний, при этом численность диатомей остается высокой, а в отложениях оз. Лача достигает своего максимума - 4,5 млн. В суббореале в оз. Лача в иловых отложениях возрастает роль планктонных диатомей, которые теперь составляют иногда до $50 \%$ створок в осадках. Общее содержание створок несколько ниже, чем в атлантике, но по-прежнему остается высоким. В это время оно наивысшее в оз. Лача - до 3 млн. Для отложений озер, наряду с видами обрастаний, становятся характерными диатомеи Melosira ambigua (Grun.) O. Müll., M. granulata (Ehr.) Ralfs.

Такой состав диатомовых комплексов сохраняется в отложениях озер и в субатлантическое время, когда численность диатомей несколько снижается.

В различные периоды существования озер изменялись характер и темп седиментации осадков, что хорошо прослеживается по изменению соотношения песчаных, алевритовых и пелитовых фракщий, содержанию органического вещества и аутигенного кремнезема (см. рис. 2). Эти изменения обусловлены общими изменениями климатической обстановки на протяжении поздне- и послеледниковья.

Региональные особенности процессов формирования осадков в исследованных озерах выразились в различном содержании органического вещества, накопление которого началось уже в позднеледниковье. До 
конца бореала седиментация его была наибольшей в Кубенском озере. C начала атлантики и по настоящее время высокие показатели накопления органического вещества свойственны илам оз. Лача, они ниже в Воже и наименьшие в Кубенском. Это связано с изменением гидрологического режима оз. Лача в связи со стоком его на восток по р. Сухоне. После прорыва р. Сухоны в отложениях озера изменяется характер диатомовых комплексов: более существенную роль начинают играть планктонные диатомеи.

В оз. Воже по составу диатомей в отложениях отмечается повышение уровня в пребореале, когда озеро, возможно, было бессточным. Сток в оз. Лача по р. Свиди возник, вероятно, в начале бореала. В оз. Лача с момента его обособления сохранился устойчивый режим мелководного сильно зарастающего макрофитами водоема. С бореального времени в озере начинают накапливаться илы с высоким содержанием органического вещества, чему способствует поступление вод из оз. Воже.

Диатомовые комплексы поздне- и послеледниковых отложений озер Лача, Воже и Кубенское свидетельствуют о формировании осадков в условиях мелководных, в той или иной степени зарастающих макрофитами обширных водоемов. По составу диатомей они резко отличаются от одновозрастных комплексов в отложениях глубоководного Онежского озера (Давыдова, 1976).

\section{Л ИТЕ РА Т У РА}

Арсл анов Х. А., Ауслендер В.Г., Громова Л. И., Зубков А. Н., Хому то в а В. И. Палеогеографические особенности и абсолютный возраст максимальной стадии валдайского оледенения в районе Кубенского озера. - Докл. АН CCCP, 1970, т. 195, № 6, с. 1395-1398.

А усленде р В. Г., Г ей В. П. История развития Кубено-Сухонской озерной впадины в плейстоцене и голоцене. - Материалы II симпозиума по истории озер Северо-Запада СССР. Минск, 1967, с. 10-13.

А услендер В. Г., А.р л анов Х. А., Г арк уша В. И. К вопросу о стратиграфии и геохронологии позднеплейстоценовых отложений Кубено-Сухонской низины и прилегающих водоразделов. - В кн.: Периодизащия и геохронология плейстоцена (материалы к симпозиуму). Л., 1970, с. 92-95.

Д а в ыдо в а Н. Н. Комплексы диатомей в донных отложениях Онежского озера. В кн.: Палеолимнология Онежского озера. Л., 1976, с. 130-191.

Квасов Д. Д. Позднечетвертичная история крупных озер и внутренних морей Восточной Европы. Л., 1975.

К урочкин а А. А. Литология и хемостратипрафия донных отложений Онежского озера. - В кн.: Палеолимнология Онежского озера. Л., 1976, с. 74-129.

С еменович Н. И., К урочкин а А. А., Галковская Г. Ф., Ш теренберг Л. Е. Глинистые минералы в осадках Онежского озера. - Докл. АН СССР, т. 206. № 6,1972 , с. $1445-1448$.

С е м е н о и ч Н. И. Донные отложения Онежского озера. Л., 1976.

Х о м у то в а В. И. Результаты палинологического изучения прунтовой колонки. - В кн.: Кубенское озеро. Л., 1974, с. 26-28.

Хо м у то в а В. И. Первые данные по геохронологии донных отложений оз. Лача. В кн.: Озера Воже и Лача. Л., 1975, с. 31-34.

\section{Северо-Западное территориальное} геологическое управление 
V. GEI, N. DAVODOVA, A. KUROTSKINA,

V. SOKOLOV, V. SLOKOV

\section{JARVESETETE KUJUNEMISE ISEÄRASUSED \\ HILISJAAAJAL JA PÄRAST JÄÄAEGA}

On esitatud Kubeni, Voža, Latša ja Aänisjärve põhjasetete kompleksse uurimise tulemused. Nimetatud järvede areng on tihedas seoses mandrijää taandumisega. Hilisjääajal ja pärast jääaega toimus järvedes setete kuhjumine erinevalt: allerödis ja drüüases settisid Aänisjärves viirsavid, madalaveelistes järvedes aga jämedateralisemad setted, holotseenis kuhjusid homogeensed kihistumata savid ja mudad. Autigeense räni sisaldus setetes sôltub ränivetikate hulgast.

V. GAY, N. DAVYDOVA, A. KUROCHKINA,

V. SOKOLOV, V. SHLYKOV

\section{LAKE SEDIMENTATION IN THE LATE- AND POST-GLACIAL}

Sediment cores from the lakes in the north-west of the USSR - Lacha, Vozhe, Kubenskoye and Onega - were studied. The Onega is a deep and oligotrophic lake and the first three ones - shallow and mesotrophic. The sedimentation process started during the deglaciation of the territory, when varved deposits were formed. In the Onega those were varved clays, in the shallow lakes - clays with layers of sands and silts. Their formation was over in $\mathrm{DR}_{3}$, when homogeneous clays began to originate. The warming of the climate caused a growth of biological productivity of aquatic and terrestrial communities and a formation of silts with a high organic matter content in the lakes. Silt sedimentation started in the Kubenskoye in PB, in the Vozhe and Lacha in BO, and in the Onega - in AT. In the Vozhe clay minerals originated from the ancient Permian deposits of the watershed, and in the Onega from younger derivates of the Baltic Shield rocks. In lake sediments, silicon concentration correlates with the amount of diatom shells. Their fluctuations show the changes in the intensity of biological processes in the lakes during the Late- and Post-Glacial. 